\title{
New records of Moluchia strigata (Blanchard, 1851) (Blattodea: Ectobiidae) in Mediterranean Matorral, Central Chile
}

\section{Nuevos registros de Moluchia strigata (Blanchard, 1851) (Blattodea: Ectobiidae) en el Matorral Mediterráneo de Chile Central}

\author{
Cristian A. Villagra* \& Constanza Schapheer \\ Instituto de Entomología, Facultad de Ciencias Básicas, Universidad Metropolitana de Ciencias de la Educación. Av. José \\ Pedro Alessandri 774, Ñuñoa, Santiago, código postal 7760197. \\ *author for correspondence: cristian.villagra@umce.cl
}

\begin{abstract}
Despite of commonly been associated with antrophized habitats, most cockroaches do not overlap with human habitats (Schal et al. 1984, Frank \& Lounibos 2010, Maekawa \& Nalepa 2011). Wild Blattodea have been reported as relevant participants of nutrient cycling and organic matter turnover (Irmer \& Furch 1979, Geng \& Côté 2002). Moreover, cockroaches are part of several ecological interactions, including pollination (Bell et al. 2007, Nagamitsu \& Inoue 1997, Momose et al. 1998, Vlasáková et al. 2008). Therefore, in addition to its zoological and evolutionary relevance, these insects can be used for environmental monitoring and litter quality bioindicators (Gerlach et al. 2013).
\end{abstract}

Native Chilean cockroaches have been seldom studied and information on its distribution is scarce and incomplete (Moroni \& Camousseight 1976). Despite of this, there are at least 12 described species belonging to four different genuses: Eurycotis Stal 1838, Ischnoptera Burmeister 1838, Phidon Rehn 1933, Epilampra Burmeister 1838 and Moluchia (Camousseight 2008, Beccaloni 2015).

To this date there is no updated revision on Chilean native cockroach distribution, nor published studies on their zoology, behavior or ecology. The most recent publications on native Chile cockroaches corresponded exclusively to reviews and records from entomological collections (Camousseight 2008, Moroni \& Camousseight 1976). From the available information, there are scattered records for several neotropical genera of Ectobiidae, as Ischnoptera, Lamproblatta Hebard 1919 y Neoblattella Shelford 1911 living in association with native plants; in leaves, under fallen stems and within plant's structures such as bracts and inflorescence buds (Rehn \& Hebard 1916, Roth \& Willis 1960).

The genus Moluchia Rehn, 1933 corresponds to a
Neotropical cockroach group (Blattodea) belonging to the family Ectobiidae Brunner von Wattenwyl, 1865 (Beccaloni 2015). To the best of our knowledge, the only key for identifying Moluchia species was published by Rehn in 1933, where he used number of flanges per tergite as main diagnosis feature ("tergal specialization") (Fig. 2C). This was associated to a glandular specialization in male dorsal side of abdomen (Rehn 1933). Due to the specificity of this trait, Rehn's key does not allow sorting nymphs or females specimens. Moreover his work does not include the species described by Princis, M. dahli and M. brasiliensis (Princis 1952, Rehn 1933).

In this note, we report new records for M. strigata based on: i. Active collection followed by laboratory rearing and ii. Entomological collection surveying on main national collections. Historical records of $M$. strigata comprehend Arauco, Eastern Island, Valparaíso Province, unspecified exact location of collect (Rehn 1933, Moroni \& Camousseight 1976).

During June 2015 we found native cockroach nymphs beneath dead leaves material from Puya chilensis (Bromeliaceae) in Córdova Ravine Natural Sanctuary ("Quebrada de Córdova", 3326'S - 71³9'W) in El Tabo County, San Antonio Province, Valparaíso Region, Chile (Fig. 1). According to the National System of Protected Wild Areas (SNASPE) this ravine is classified among priority sites type III (CONAF 1996). "Quebrada de Córdova" is an east-west direction ravine with sclerophyllous relictual forest (Perez \& Villagrán 1985) where is possible find several Chilean Matorral endemic plant species classified as "rare at national level" (CONAF 1989), the climate is Mediterranean with marine influence (Perez \& Villagrán 1985).

We made active collection at three points from east to west 
the "Quebrada" during June 2015 and captured various immature stages of unidentified Moluchia sp. Due to the fact that the only available key is focused on male adults, in order to identify specimens we reared these collected cockroaches under laboratory conditions $\left(12 / 12 \mathrm{hrs} .20^{\circ} \mathrm{C}\right.$ and $50 \% \mathrm{RH})$ in plastic boxes $(660 \mathrm{cc})$, with leaves of $P$. chilensis feeding on dog food pellet, bee pollen granules (Goldenhills ${ }^{\circledR}$ ) and sliced carrots ad libitum. Finally, in August 2015 we obtained imagoes, we made identification according to Rehn's key corresponding these cockroaches to M. strigata (Figure 2).

During 2014 to August 2015, we made a comprehensive revision of native specimens deposited in main Chilean entomological collections (MCCN, IEUMCE, MEUC, MZUC, CEUTAL and SAG). According to label data from specimens identified as M. strigata, we were able to determine the presence of imagoes from; Valparaíso Region: Recreo collected in October 1968, Casablanca found in November 2000 and Maule Region: Vilches Alto trapped in December 1999 and Vichuquén collected in October 1992.

Summarizing, based on evidence gathered from field collection, laboratory rearing and entomological collections survey, we can suggest that $M$. strigata share the same microhabitat with other native cockroach (Phidon Rehn 1933 genus). We also found in P. chilensis (Bromeliaceae) litter during our field collections. We propose that there must be a strong connection between Moluchia cockroaches and Chilean Bromeliaceae species as it is reported for other Chilean cockroach family Epilampra hualpensis
Uribe 1978 (Blaberidae) (Uribe 1977). Furthermore, several tropical species have been described associated to bromeliads (Bell et al. 2007, Frank \& Lounibos 2010, Roth \& Willis 1960, Rocha e Silva Albuquerque \& Lopes 1976). Complementarily, based on the observation of captive M. strigata cockroaches feeding on pollen, it is possible to suggest a florivorous role of this neotropical lineage. Furthermore, considering temporal data obtained from specimens of this cockroach species we found in entomological collections. We propose that $M$. strigata phenology follow a similar seasonality as other neotropical cockroach species, meaning: A reproductive peak around early spring (Bell et al. 2007), where most native flora is blooming. Therefore, the strength association between these insects and floral resources it is reinforced.

Future work must be developed in order to reveal the extent of this species distribution in central Chile and evaluate if collection localities belongs to a continuum distribution zone between Valparaiso Region to Maule Region (approximately $366 \mathrm{~km}$ away) or alternatively $M$. strigata records may correspond to fragmented patches within remaining Mediterranean Matorral, this considering the current impact of habitat homogenization activities in Central Chile such as forestry, agriculture and housing (Andrade \& Hidalgo 1996). Furthermore, detailed active collection studies have to be made in order to assess conservation status for this and other Chilean native cockroach species. A couple of specimens collected for this work were deposited in the entomological collection of the Museo Nacional de Historia Natural, Santiago, Chile (MCCN).
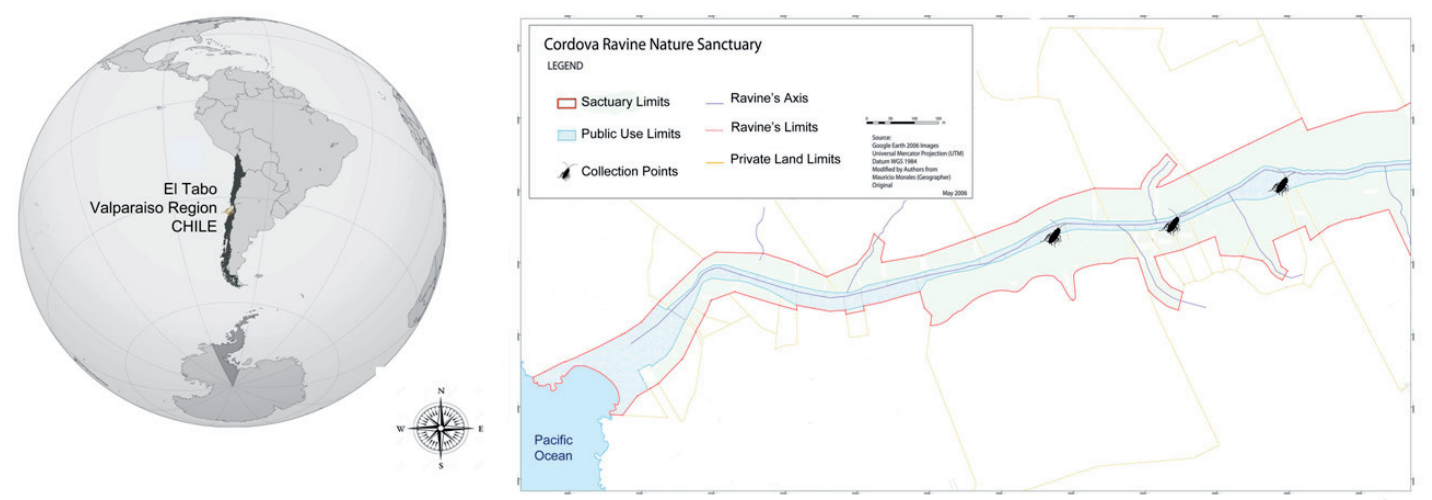

Figure 1. Collection Points Location for M. strigata in Quebrada de Córdova Natural Sanctuary. Left side of the panel show globe highlightin El Tabo, Valparaiso Region, Chile. Right side of panel detail collection points along East-West axis of ravine at the field site. Upper left show legend for Natural Sanctuary map.

Figura 1. Ubicación de las colectas de M. strigata en Quebrada de Córdova. Lado izquierdo muestra globo terráqueo con detalle de ubicación del sitio de muestreo, lado derecho detalla puntos de colecta en el eje Este-Oeste a lo largo de la quebrada. Legenda del mapa esta ubicada en esquina superior izquierda del mismo. 

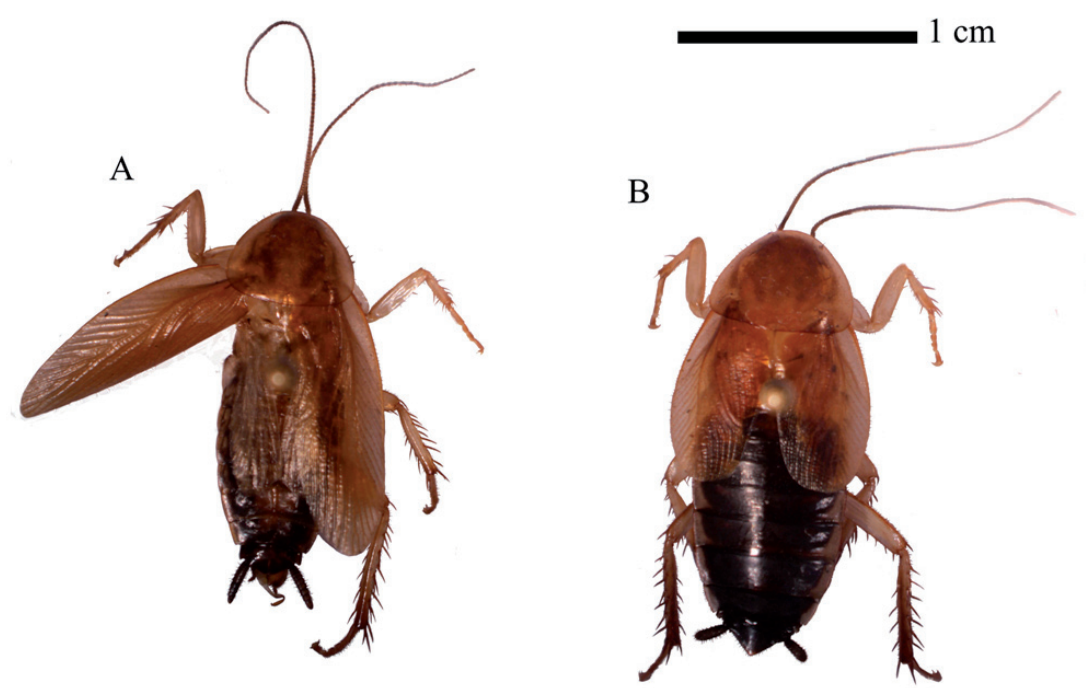

$\mathrm{C}$

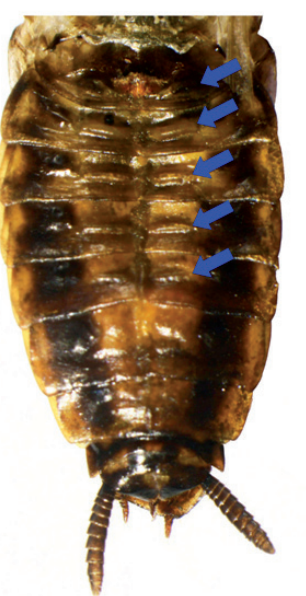

$0.5 \mathrm{~cm}$

Figure 2. Dorsal views M. strigata, (A) correspond to a male and (B) to female adults. $1 \mathrm{~cm}$ scale. (C) Detail of male's abdomen (wings removed), tergal specialization is indicated with blue arrows, $0.5 \mathrm{~cm}$ scale.

Figure 2. Vistas dorsales de M. strigata, (A) macho y (B) hembra. Escala corresponde a $1 \mathrm{~cm}$. (C) Detalle del abdomen del macho (las alas fueron removidas), la especialización tergal está señalada con flechas azules, Escala corresponde a $0,5 \mathrm{~cm}$

\section{ACKNOWLEDGEMENTS}

We thanks Dr. Alejandro Vera and Dr. Daniel Frías, Instituto de Entomología, UMCE; Mario Elgueta, MCCN Danilo Cepeda MEUC; Sergio Rothmann, Laboratorio SAG Lo Aguirre, Myriam Ramírez y Profesor Jorge Artigas, UDEC Cristián Muñoz, UTAL, Nicolás Inostroza, CODECIAM, and Professor Claudio Medina. This research was funded by DIUMCE FIBE 0812 granted to Cristian A. Villagra and Rufford Small Grant N¹8114-1, Rufford Fundation, granted to Constanza Schapheer.

\section{BIBLIOGRAFÍA}

Andrade, B. \& Hidalgo, R. 1996. La Zona Costera y los Instrumentos de Planificación Territorial: Litoral de la
Provincia de Petorca. Revista Geográfica de Chile Terra Australis 41:111-120.

Beccaloni, G. 2015. Citing Electronic Resources. Cockroach Species File Online. Version 5.0/5.0. World Wide Web electronic publication, p.http://cockroach.speciesfile.org/. Accesado: Septiembre 5, 2015.

Bell, W., Roth, L. \& Nalepa, C. 2007. Cockroaches Ecology, Behavior and Natural History. The Johns Hopkins University Press. Press, ed., Baltimore. 230 pp.

CAmousseight, A. 2008. Orden Blattodea (baratas, cucarachas). In Comisión Nacional del Medio Ambiente, ed. Biodiversidad de Chile, Patrimonio y Desafíos. Santiago de Chile, 639 pp.

CONAF. 1989. Libro Rojo de la Flora Terrestre de Chile, Santiago de Chile, Corporación Nacional Forestal. 157pp.

CONAF. 1996. Libro Rojo de los Sitios Prioritarios para la Conservación de la Diversidad Biológica en Chile. Santiago de Chile. Corporación Nacional Forestal. 203 pp. 
FrANK, J.H. \& LouniBos, L.P. 2010. Insects and allies associated with bromeliads: a review. Terrestrial arthropod reviews $1(2): 1-23$.

Gerlach, J., Samways, M. \& Pryke, J. 2013. Terrestrial invertebrates as bioindicators: An overview of available taxonomic groups. Journal of Insect Conservation 17:831850 .

Maekawa, K. \& Nalepa, C. 2011. Biogeography and Phylogeny of Wood-feeding Cockroaches in the Genus Cryptocercus. Insects 2(4):354-368.

Momose, K., Hatada, A., Yamaoka, R., \& Inoue, T. 1998. Pollination Biology of the Genus Artocarpus, Moraceae. Tropics 7:165-172.

Moroni, J. \& Camousseight, A. 1976. Aporte al Estudio de las Baratas de Chile. Boletín de la Sociedad de Biología de Concepción, 1:43-51.

Nagamitsu, T. \& Inoue, T. 1997. Cockroach pollination and breeding system Uvaria Elmeri (Annonaceae) in a lowland mixed-dipterocarp forest in Sarawak. American Journal of Botany 84(2):208-213.

Pérez, C. \& Villagrán, C. 1985. Distribución de abundancias de especies en bosques relictos de la zona mediterránea de Chile. Revista Chilena de Historia Natural 58:157-170.
Princis, K. 1952. Blattariae. Reports of The Lund University, 1-11. Rehn, J. 1933. On the Dermaptera and Orthoptera of Chile. Part One. Transactions of the American Entomological Society 59(3):159-190.

Rehn, J. \& Hebard, M. 1916. Studies in Dermaptera and Orthoptera of the coastal plain and piedmont region of the southeastern United States. Proceedings of the Academy of Natural Sciences of Philadelphia 68(2):87-314.

Rocha E Silva Albuquerque, L. \& Lopes, S. M. R. 1976. Blattaria de Bromelia (Dictyoptera). Revista Brasileira de Biologia 36(4):973-901.

Roth, L.M. \& Willis, E.R. 1960. The Biotic Associations of Cockroaches. Smithsonian Miscellaneous Collections 141:1-439.

Schal, B.Y.C., Gautier, J. \& Bell, W.J. 1984. Behavioural Ecology of Cockroaches. Biological Reviews 59:209-254.

Uribe, L. 1977. Epilampra huelpensis, Nueva Especie de Blaberido Chileno (Insecta Dictyoptera, Blattaria). Boletín de la Sociedad de Biología de Concepción 51(1):269-275.

Vlasáková, B., Kalinová, B., Gustafsson, M. H. G., \& Teichert, H. 2008. Cockroaches as pollinators of Clusia aff. sellowiana (Clusiaceae) on inselbergs in French Guiana. Annals of Botany 102:295-304.

Recibido: 07.08.15

Aceptado: 12.01.16 